\title{
Religiusitas dan Kecenderungan Melakukan Kekerasan dalam Rumah Tangga
}

\author{
Zulfa Rahmah, Syafrilsyah, Fatmawati \\ Fakultas Psikologi Universitas Negeri Ar-Raniry Banda Aceh
}

\begin{abstract}
Family is the smallest unit of the organization which can develop someone's character. Every human being hopes to have tranquility, affective, and merciful family. However, domestic violence case is increasing each year. It is the sign that human beings' morality is decreasing day by day as well as a misunderstanding of religious teachings. Thus, this study aimed to find out the relationship between religiosity and the tendency of committing domestic violence among husband in Banda Aceh city. This study used a quantitative method with a purposive sampling technique. The participants recruited were 120 husbands. The result showed there was a negative and significant relationship between religiosity and the tendency of committing domestic violence among husband in Banda Aceh city with Pearson correlation value $r=-0,788, p=0,00(p=<0,05)$. The finding of this study implied that religiosity has a significant contribution toward the tendency of committing domestic violence in the family. Hence, understanding religious teaching is significantly needed for achieving a peaceful family.
\end{abstract}

Keywords: character; children; violence

\begin{abstract}
Abstrak
Keluarga adalah unit terkecil dari sebuah organisasi yang dapat membangun karakter seseorang. Setiap manusia berharap mendapatkan keluarga yang sakinah mawaddah warahmah, tetapi kenyataannya kasus KDRT terus meningkat setiap tahunnya. Hal ini menunjukkan moral seseorang semakin hari semakin rusak dan juga pemahaman agama yang kurang serta keliru. Untuk itu, penelitian ini bertujuan untuk mengetahui hubungan antara religiusitas dengan kecenderungan KDRT oleh suami di Kota Banda Aceh. Penelitian ini menggunakan metode kuantitatif dengan pengambilan sampel berdasarkan teknik purposive sampling. Sampel penelitian ini berjumlah 120 orang dan hasil penelitian menunjukkan bahwa terdapat hubungan yang negatif dan signifikan antara religiusitas dengan kecenderungan KDRT oleh suami di Kota Banda Aceh dengan nilai uji korelasi Pearson r= -0,788, p=0,00 $(p=<0,05)$. Hasil penelitian menunjukkan bahwa religiusitas memiliki kontribusi yang besar terhadap kecenderungan melakukan KDRT dalam keluarga, sehingga pemahaman agama yang baik sangat diperlukan agar tercipta keluarga yang harmonis.
\end{abstract}

Kata Kunci: religiusitas; kekerasan dalam rumah tangga; suami 
Dalam perkawinan, setiap pasangan memimpikan dapat membangun keluarga yang harmonis, bahagia, saling mencintai, sakinah, mawaddah, dan rahmah (perasaan tenang, cinta, dan kasih sayang). Keluarga bahagia secara duniawi maupun ukhrawi merupakan tujuan setiap muslim, karena keluarga merupakan fondasi yang kokoh bagi terbangunnya kehidupan masyarakat yang baik (Bambang, dalam Situmorang \& Syifa, 2008).Tetapi faktanya banyak keluarga yang ternyata tidak harmonis, justru merasa tertekan dan sedih karena terjadinya Kekerasan Dalam Rumah Tangga (KDRT), baik kekerasan yang bersifat fisik, psikologis atau kejiwaan, seksual, emosional, maupun penelantaran keluarga. KDRT dapat terjadi di semua lapisan sosial masyarakat maupun latar belakang pendidikan. Hal itu menunjukkan bahwa penyebabnya bukan karena faktor situasi ekonomi maupun tinggi rendahnya pendidikan seseorang saja. Ketidaksetaraan kedudukan peran sosial perempuan, tidak saling mengerti dan menghargai antara suami istri, serta ilmu agama yang tidak diamalkan dalam kehidupan berumah tangga juga menjadi penyebab KDRT (Muttaqin, Murtadha, \& Umrina, dalam Yuhono, 2018).

At-Tharirah (2006) menjelaskan bahwa sekitar 24 juta perempuan dari 217 juta penduduk Indonesia terutama di pedesaan mengakui pernah mengalami kekerasan dan yang terbesar adalah KDRT. Komisi Nasional Perempuan pada tahun 2001 melakukan survei pada 14 daerah di Indonesia (Aceh, Palembang, Jambi, Bengkulu, Jakarta, Jawa Barat, Jawa Tengah, Yogyakarta, Jawa Timur, Kalimantan Barat, Maluku, Sulawesi Utara, Sulawesi Selatan, dan Nusa Tenggara Timur) yang menunjukkan bahwa kaum perempuan paling banyak mengalami kekerasan dan penganiayaan oleh orang-orang terdekatnya serta tindak perkosaan di lingkungan komunitasnya sendiri.

Kasus KDRT ini menjadi sangat riskan terjadi di Aceh, padahal Aceh sendiri merupakan satu-satunya provinsi di Indonesia yang diberi hak untuk melaksanakan syari'at Islam dengan benar. Hal ini berarti bahwa setiap masyarakat yang ada di Aceh seharusnya bersikap lebih religius dengan adanya syari'at Islam ini. Penerapan syariat Islam di era otonomi khusus untuk Aceh, akrab dengan kata-kata "penerapan syariat Islam secara kaffah di Aceh", yang bermakna 
sebuah usaha untuk memberlakukan Islam sebagai dasar hukum dalam tiap tindak-tanduk umat muslim secara sempurna.

Dalam setiap ikatan pernikahan, semua orang menginginkan untuk dapat membangun bahtera rumah tangga perkawinan yang harmonis, damai, bahagia, dan sejahtera. Tentunya dalam kesejahteraan sebuah pernikahan harus didasari tulus, saling mencintai, dan menerima ketetapan-Nya. Sesuai firman Allah SWT dalam Al-Quran sebagai berikut.

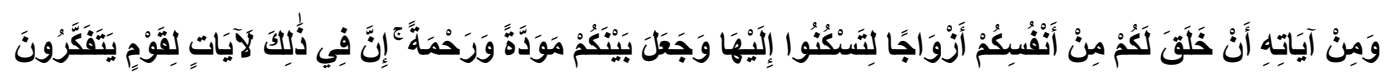

Artinya: Dan di antara tanda-tanda kekuasaan-Nya ialah Dia menciptakan untukmu isteri-isteri dari jenismu sendiri, supaya kamu cenderung dan merasa tenteram kepadanya, dan dijadikan-Nya di antaramu rasa kasih dan sayang. Sesungguhnya pada yang demikian itu benar-benar terdapat tandatanda bagi kaum yang berfikir (QS. Ar-Rum :21).

Dari ayat surat Ar Rum 21 tersebut, Allah SWT menyampaikan bahwa manusia diciptakan berpasangan antara istri dan suami untuk mendapatkan ketenangan, ketentraman, dan kasih sayang. Hal tersebut merupakan tanda kuasa Allah SWT dan nikmat yang diberi bagi mereka yang bisa mengambil pelajaran. Pada kenyataannya tidak semua tatanan kehidupan dalam keluarga dapat berjalan dengan harmonis sesuai dengan yang diharapkan, sebaliknya justru kadang dirasakan adanya ketegangan dan konflik, adanya perasaan tidak nyaman, rasa takut dan tertekan. Ketidakharmonisan dalam rumah tangga tersebut dapat diindikasikan bahwa terdapat masalah dalam keluarga tersebut. Pada umumnya KDRT merupakan salah satu penyebab hilangnya keharmonisan dalam keluarga (Yuhono, 2018)

Terdapat banyak sekali hal-hal yang diduga melandasi terjadinya kekerasan dalam rumah tangga, antara lain yaitu adanya budaya patriarki yang kuat dalam masyarakat, ketidakmandirian istri, tingkat pendidikan, ketidakpuasan perkawinan, dan sebagainya. Dari hasil penelitian yang telah dilakukan oleh Puspitaningtyas (2004), ada beberapa hal yang melandasi terjadinya KDRT, yaitu: faktor kepribadian suami dan istri yang saling mendukung terjadinya KDRT, bentuk komunikasi yang buruk yaitu satu arah, menempatkan budaya patriarki dan nilai tradisional dalam taraf yang tidak wajar, serta adanya frustasi-frustasi yang dialami oleh suami di luar rumah. 
Pendapat tersebut juga didukung dengan hasil survei yang dilakukan oleh Rifka Annisa Women's Crisis Center yang menyatakan bahwa adanya pemahaman nilai-nilai agama dan budaya yang keliru, menjadikan istri "hak milik" suami yang boleh diperlakukan sesuka hati (Situmorang \& Syifa, 2008). Selain itu, minimnya pengetahuan dan pemahaman serta tidak dipahaminya konsep agama secara utuh tentang relasi laki-laki dan perempuan juga diduga menjadi salah satu penyebab semakin tingginya tingkat terjadinya KDRT (Bambang, dalam Situmorang \& Syifa (2008).

Hal tersebut selaras dengan pendapat Drs. H. Mawardi A.S selaku Ketua Majelis Ulama Indonesia (MUI) Lampung, yang menyatakan bahwa maraknya kasus KDRT yang terjadi akhir-akhir ini disebabkan oleh lemahnya pemahaman terhadap agama (Situmorang \& Syifa, 2008). Munculnya kekerasan yang diakibatkan oleh kurangnya seseorang dalam memahami agama juga dijelaskan oleh Takariawan (2004) yang menyatakan bahwa kekerasan terhadap perempuan dalam keluarga muslim dapat terjadi sebagai akibat dari tidak dipahaminya hukum-hukum kekeluargaan atau dipahami dengan cara yang salah.

Hurlock (2012) mengungkapkan bahwa agama terdiri atas dua unsur, yaitu unsur keyakinan terhadap ajaran-ajaran agama dan unsur pelaksanaan ajaran-ajaran tersebut. Agama merupakan salah satu faktor yang mempengaruhi seseorang dalam bersikap dan berperilaku. Keyakinan seseorang dalam beragama menurut Djarat (dalam Anggarasari, 1997) menjadi bagian integral dari kepribadian seseorang. Oleh karena itu, keyakinan itu akan mengawasi segala tindakan, perkataan, bahkan perasaannya.

Keyakinan dan pelaksanaan seseorang terhadap ajaran-ajaran agama merupakan indikasi dari religiusitas. Religiusitas diartikan oleh Dister (dalam Safaria \& Darokah, 2005) sebagai keberagamaan individu yang menunjukkan sejauh mana individu mengamalkan, melaksanakan, dan menghayati ajaran-ajaran agamanya secara terus-menerus. Dengan demikian, dapat dilihat bahwa religiusitas dapat mempengaruhi seseorang dalam bersikap dan berperilaku.

Berdasarkan paparan sebelumnya maka hipotesis dalam penelitian ini adalah terdapat hubungan yang negatif dan signifikan antara religiusitas dan kecenderungan KDRT oleh suami 
di Kota Banda Aceh, dimana semakin tinggi religiusitas maka semakin rendah kecenderungan KDRT oleh suami, dan sebaliknya semakin rendah religiusitas maka semakin tinggi kecenderungan KDRT oleh suami. Untuk lebih jelas dapat dilihat pada ilustrasi kerangka konseptual berikut ini.

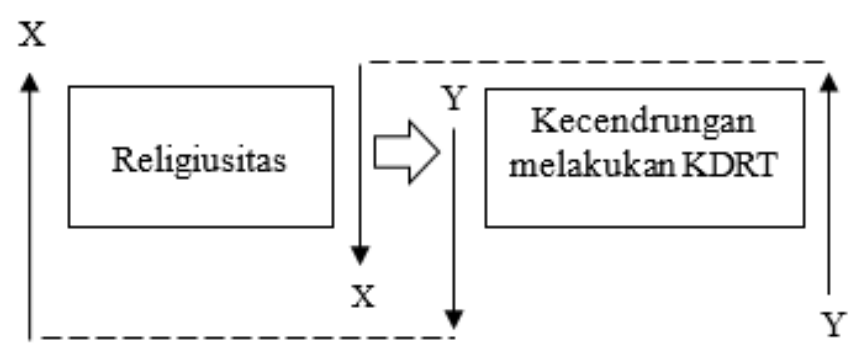

Gambar 1.1 Kerangka Konseptual

\section{Metode}

Rancangan Penelitian

Pendekatan yang digunakan dalam penelitian ini adalah pendekatan kuantitatif karena analisis data akhir dilakukan dengan uji statistik. Adapun metode penelitian yang digunakan adalah korelasional yaitu untuk mengetahui hubungan antara variabel bebas dengan variabel terikat, dalam hal ini adalah hubungan antara tingkat religiusitas dengan kecenderungan melakukan kekerasan dalam rumah tangga (KDRT) oleh suami di Kota Banda Aceh.

\section{Sumber Data}

Populasi dalam penelitian ini adalah laki-laki sudah menikah yang berdomisili di Kota Banda Aceh. Teknik pengambilan sampel yang akan digunakan ialah purposive sampling. Adapun kriteria subjek pada penelitian ini adalah laki-laki sudah menikah (suami) yang berdomisili di Banda Aceh dan telah menikah selama 1 tahun. Berdasarkan kriteria tersebut diperoleh sampel sebanyak 120 orang yang bersedia menjadi partisipan. 


\section{Teknik Pengumpulan Data}

Penelitian ini menggunakan kuesioner yang berbentuk skala psikologistentang variabel yang diteliti, yakni variabel religiusitas dan kecenderungan melakukan KDRT. Jawaban dalam skala ini dinyatakan dalam empat kategori yaitu, Sangat Setuju (SS), Setuju (S), Tidak Setuju (TS), dan Sangat Tidak Setuju (STS). Skala religiusitas dan skala kecenderungan melakukan KDRT ini disusun dengan menggunakan skala Likert. Skala religiusitas disusun berdasarkan dimensi-dimensi religiusitas yang dikemukakan oleh Ancok dan Suroso (2011) yang terdiri dari lima dimensi yaitu: dimensi akidah, dimensi syari'ah, dimensi akhlak, dimensi pengetahuan agama, dan dimensi penghayatan. Jumlah keseluruhan aitem pada skala ini adalah 64 pernyataan. Skala ini melewati uji validitas isi yang dilakukan melalui expert judgment. Setelah dilakukan uji daya beda aitem, skala religiusitas menunjukkan bahwa dari 64 aitem yang diujicobakan, terdapat 48 aitem dengan koefisien korelasi di atas 0,30 dengan rentang dari -0,156 hingga 0,802, yang menghasilkan reliabilitas konsistensi internal religiusitas yaitu 0,962. Contoh aitem dalam skala ini diantaranya adalah: "saya percaya bahwa apabila saya sakit itu merupakan cobaan dari Allah" (Dimensi Akidah); "memperdalam ilmu agama, seperti mendengar kajian merupakan hal penting bagi saya" (Dimensi Syari'ah); "saya mengucapkan salam ketika berjumpa dengan teman" (Dimensi Akhlak); "Al-Quran menceritakan tentang segala kehidupan umat manusia termasuk kisah-kisah umat pada jaman dahulu" (Dimensi Pengetahuan Agama);dan "saya merasa lebih tenang setelah menjalankan shalat" (Dimensi Penghayatan)

Skala kecenderungan melakukan KDRT disusun berdasarkan bentuk-bentuk KDRT yang sesuai dengan Undang-Undang Nomor 23 Tahun 2004 Pasal 7, 8, dan 9 tentang Penghapusan Kekerasan Dalam Rumah Tangga (PKDRT). Kekerasan dalam rumah tangga ini memiliki 4 bentuk yaitu kekerasan fisik, kekerasan psikis, kekerasan seksual, dan penelantaran keluarga (kekerasan ekonomi). Jumlah keseluruhan aitem pada skala ini adalah 42 pernyataan. Skala ini melewati uji validitas isi yang dilakukan melalui expert judgment. Setelah dilakukan uji daya beda aitem, skala kecenderungan melakukan KDRT menunjukkan bahwa dari 42 aitem yang diujicobakan dan diperoleh seluruh aitem dengan koefisien korelasi di atas 0,30 dengan rentang dari 0,355 hingga 0,865, yang menghasilkan reliabilitas konsistensi internal 
kecenderungan melakukan KDRT yaitu 0,977. Contoh aitem untuk skala ini diantaranya adalah: "saya tidak pernah berbuat kasar dengan istri saya" (Aspek Kekerasan Fisik); "mengancam mengusir istri pernah saya lakukan ketika sangat emosi" (Aspek Kekerasan Psikis); "saya tidak mau berhubungan seksual ketika istri yang mengajaknya" (Aspek Kekerasan Seksual); dan "pendidikan anak-anak menjadi tanggung jawab istri saya" (Aspek Kekerasan Ekonomi/Penelantaran Rumah Tangga).

\section{Teknik Analisis Data}

Langkah pertama yang dilakukan untuk menganalisis data penelitian ini yaitu dengan cara uji prasyarat. Uji prasyarat yang dilakukan dalam penelitian ini, yaitu uji normalitas dan uji linieritas.Langkah kedua yang dilakukan setelah uji asumsi terpenuhi yaitu uji hipotesis penelitian. Dalam rangkamenguji hipotesis yang diajukan pada penelitian ini yaitu bahwa religiusitas berkorelasi terhadap kecenderungan melakukan KDRT oleh suami di Kota Banda Aceh, maka teknik analisis data yang digunakan yaitu dengan metode korelasi product moment dari Pearson. Analisis penelitian data yang dipakai adalah dengan bantuan komputer program SPSS version 20.0 for Windows.

\section{Hasil}

Penelitian dilakukan pada suami di Kota Banda Aceh dengan jumlah sampel penelitian sebanyak 120 orang yang sudah menikah selama 1 tahun. Data demografi sampel yang diperoleh dari penelitian ini berdasarkan usia yaitu, paling banyak berusia 23-35 yaitu berjumlah 53 orang, dibandingkan yang berusia 36-45 berjumlah 46 orang dan berusia 46-55 berjumlah 21 orang. Jika berdasarkan pekerjaan, sampel penelitian lebih banyak yang berkategori lainnya yaitu berjumlah 45 orang, dibandingkan dengan yang bekerja sebagai PNS berjumlah 36 orangdan wirausaha berjumlah 39 orang. Selanjutnya, yang berpenghasilan > 3.000.000 lebih banyak yaitu berjumlah 76 orang, dibandingkan dengan yang berpenghasilan Rp. 1.000 .000 - Rp 3.000.000 berjumlah 39 orang dan kurang dari Rp. 1.000 .000 berjumlah 37 
orang. Berikut adalah hasil kategorisasi subjek penelitian berdasarkan skala religiusitas dan skala kecenderungan melakukan KDRT.

\section{Skala Religiusitas}

Deskripsi data hasil penelitian adalah sebagai berikut.

Tabel 1.Deskripsi Data Penelitian Skala Religiusitas

\begin{tabular}{ccccccccc}
\hline \multirow{2}{*}{ Variabel } & \multicolumn{4}{c}{ Data Hipotetik } & \multicolumn{4}{c}{ Data Empirik } \\
\cline { 2 - 10 } & Xmaks & Xmin & Mean & SD & Xmaks & Xmin & Mean & SD \\
\hline Religiusitas & 192 & 48 & 120 & 24 & 192,0 & 144,0 & 175,9 & 13,5 \\
\hline
\end{tabular}

Berdasarkan hasil statistik data penelitian pada tabel 1, analisis deskriptif secara hipotetik menunjukkan bahwa jawaban maksimal adalah 192, minimal 48, nilai rerata 120, dan standar deviasi 24. Sementara data empirik menunjukkan jawaban maksimal adalah 192, minimal 144, nilai rerata 175,9, dan standar deviasi 13,5. Deskripsi data hasil penelitian tersebut dapat dijadikan batasan dalam pengkategorian sampel penelitian yang terdiri dari tiga kategori, yaitu rendah, sedang, dan tinggi dengan metode kategorisasi jenjang (ordinal).

Tabel 2. Kategorisasi Religiusitas Suami di Kota Banda Aceh

\begin{tabular}{cccc}
\hline Kategori & Interval & Frekuensi (n) & Persentase (\%) \\
\hline Rendah & $\mathrm{X}<(175,9-13,5)$ & 23 & 19,2 \\
Sedang & $(175,9-13,5) \leq X<(175,9+13,5)$ & 73 & 60.8 \\
Tinggi & $(175,9+13,5) \leq X$ & 24 & 20 \\
\hline \multicolumn{2}{r}{ Jumlah } & $\mathbf{1 2 0}$ & $\mathbf{1 0 0}$ persen \\
\hline
\end{tabular}

Hasil kategorisasi religiusitas pada tabel 2 tesebut, menunjukkan bahwa mayoritas suami yang berada di Kota Banda Aceh memiliki tingkat religiusitas pada kategori sedang yaitu sebanyak 73 (60.8 persen), sedangkan sisanya berada pada kategori rendah yaitu sebanyak 24 (20 persen) dan kategori tinggi yaitu sebanyak 23 (19,2 persen). Kategori sedang ini menunjukkan bahwa religiusitas pada suami di Kota Banda Aceh berada pada taraf menengah. 


\section{Skala Kecenderungan Melakukan KDRT}

Deskripsi data hasil penelitian adalah sebagai berikut.

Tabel 3. Deskripsi Data Penelitian Skala Kecenderungan Melakukan KDRT

\begin{tabular}{ccccccccc}
\hline Variabel & \multicolumn{3}{c}{ Data Hipotetik } & \multicolumn{4}{c}{ Data Empirik } \\
\hline \multicolumn{1}{c}{ Xmaks } & \multicolumn{2}{c}{ Xmin } & Mean & SD & Xmaks & Xmin & Mean & SD \\
\hline $\begin{array}{l}\text { Kecenderungan } \\
\begin{array}{c}\text { Melakukan } \\
\text { KDRT }\end{array}\end{array}$ & 168 & 42 & 105 & 21 & 84 & 42 & 53,3 & 8,2 \\
\hline
\end{tabular}

Berdasarkan hasil statistik data penelitian pada tabel 3, analisis deskriptif secara hipotetik menunjukkan bahwa jawaban maksimal adalah 168, minimal 42, nilai rerata 105, dan standar deviasi 21. Berdasarkan analisis deskriptif secara empirik menunjukkan jawaban maksimal adalah 84, minimal 42, nilai rerata 53,3, dan standar deviasi 8,2. Deskripsi data hasil penelitian tersebut dapat dijadikan batasan dalam pengkategorian sampel penelitian yang terdiri dari tiga kategori, yaitu rendah, sedang, dan tinggi dengan metode kategorisasi jenjang (ordinal).

Tabel 4. Kategorisasi Kecenderungan Melakukan KDRT pada Suami di Kota Banda Aceh

\begin{tabular}{|c|c|c|c|}
\hline Kategori & Interval & Frekuensi (n) & Persentase (\%) \\
\hline Rendah & $X<(53,3-8,2)$ & 28 & 23,3 \\
\hline Sedang & $(53,3-8,2) \leq X<(53,3+8,2)$ & 70 & 58,3 \\
\hline \multirow[t]{2}{*}{ Tinggi } & $(53,3+8,2) \leq X$ & 22 & 18,4 \\
\hline & Jumlah & 120 & 100 persen \\
\hline
\end{tabular}

Hasil kategorisasi kecenderungan melakukan KDRT pada suami di Kota Banda Aceh di atas menunjukkan bahwa mayoritas suami di Kota Banda Aceh berada pada kategori sedang yaitu sebanyak 70 (58,3 persen), sedangkan sisanya berada pada kategori rendah yaitu sebanyak 28 (23,3 persen), dan kategori tinggi 22 (18,4 persen). Kategori sedang ini menunjukkan bahwa kecenderungan melakukan KDRT pada suami di Kota Banda Aceh berada pada taraf menengah.

Setelah dilakukan kategorisasi subjek penelitian, langkah berikutnya yang harus dilakukan untuk menganalisis data penelitian yaitu dengan cara uji prasyarat. Uji prasyarat yang dilakukan dalam penelitian ini yaitu uji normalitas sebaran dan uji linieritas 
hubungan.Hasil uji normalitas sebaran data dari kedua variabel penelitian ini (relegiusitas dan kecenderungan melakukan KDRT) memperlihatkan bahwa variabel religiusitas berdistribusi normal K-S $Z=1,296$, dengan $p=0,070(p>0,05)$, sedangkan sebaran data pada variabel kecenderungan melakukan KDRT diperoleh sebaran data yang juga berdistribusi normal K-S Z $=1,268$, dengan $p=0,080(p>0,05)$. Karena kedua variabel berdistribusi normal, maka hasil penelitian dapat digeneralisasikan pada populasi penelitian ini.Sedangkan hasil uji linieritas hubungan yang dilakukan terhadap dua variabel diperoleh $F$ deviation from linearity kedua variabel di atas yaitu $F=1,520$ dengan $p=0,058 \quad(p>0.05)$, maka dapat disimpulkan bahwa terdapat hubungan yang linier antara variabel religiusitas dengan kecenderungan melakukan KDRT oleh suami di Kota Banda Aceh.

Setelah terpenuhi uji prasyarat, maka langkah selanjutnya adalah dengan melakukan uji hipotesis menggunakan analisis korelasi Pearson karena kedua variabel penelitian ini berdistribusi normal dan linier.Metode ini digunakan untuk menganalisis hubungan antara religiusitas dengan kecenderungan melakukan KDRT oleh suami di Kota Banda Aceh. Hasil analisis hipotesis menunjukkan koefisien korelasi sebesar $\mathrm{r}_{\text {hitung }}=-0,788$ yang merupakan korelasi negatif, yaitu terdapat hubungan negatif antara religiusitas dengan kecenderungan melakukan KDRT. Hubungan tersebut mengartikan bahwa jika semakin tinggi religiusitasyang dimiliki oleh suami maka semakin rendah kecenderungan melakukan KDRT oleh suami di Kota Banda Aceh.Hasil analisis penelitian ini juga menunjukkan nilai signifikansi $p=0,000$ $(p<0,05)$. Hal tersebut menunjukkan bahwa hipotesis penelitian diterima yaitu ada hubungan yang sangat signifikan antara religiusitas dengan kecenderungan melakukan KDRT oleh suami di Kota Banda Aceh.Hasil analisis pada penelitian ini juga menunjukkan sumbangan efektif dari kedua variabel yang dapat dilihat dari analisis Measures of Assocation. Hasil analisis tersebut menunjukkan nilai $R$ Square $\left(R^{2}\right)=0,621$ yang artinya terdapat 62,1 persen pengaruh religiusitas dengan kecenderungan melakukan KDRT, sementara 37,9 persen dipengaruhi oleh faktor-faktor lain. 


\section{Pembahasan}

Penelitian ini bertujuan untuk mengetahui hubungan antara tingkat religiusitas dengan kecenderungan melakukan KDRT oleh suami di Kota Banda Aceh. Analisis korelasi menunjukkan bahwa terdapat hubungan yang sangat signifikan antara religiusitas dengan kecenderungan melakukan KDRT (hipotesis diterima). Hubungan negatif ini menunjukkan bahwa tingginya religiusitas yang dimiliki oleh suami maka dapat mengurangi kecenderungan melakukan KDRT, sebaliknya rendahnya religiusitas yang dimiliki suami maka dapat meningkatkan kecenderungan melakukan KDRT tersebut.

Hal ini sesuai dengan pendapat yang disampaikan oleh (Takariawan, 2004) yang menyatakan bahwa munculnya kekerasan diakibatkan oleh kurangnya seseorang dalam memahami agama. Kekerasan terhadap perempuan dalam keluarga muslim dapat terjadi sebagai akibat dari tidak dipahaminya hukum-hukum kekeluargaan atau malah dipahami dengan cara yang salah.Salah satu faktor yang mempengaruhi terjadinya KDRT adalah interpretasi agama yang tidak sesuai dengan nilai-nilai universal agama. Agama sering digunakan sebagai legitimasi pelaku KDRT terutama dalam lingkup keluarga, padahal agama sendiri menjamin hak-hak dasar seseorang. Seperti dalam hal cara memahami nusyuz, yakni suami boleh memukul istri dengan alasan mendidik atau ketika istri tidak mau melayani kebutuhan seksual suami, maka suami berhak memukul dan memberi peringatan bagi istri akan laknat Malaikat (Mufidah, 2008). Jika KDRT terjadi disebabkan interpretasi agama yang tidak sesuai dengan universal agama, maka pelaku KDRT tidak memahami agama dengan benar. Selain itu, hasil penelitian ini juga mendukung penelitian sebelumnya yang dilakukan oleh Situmorang \& Syifa (2008) yang menyebutkan hal yang sama bahwa terdapat korelasi negatif yang sangat signifikan antara religiusitas terhadap intesitas melakukan kekerasan terhadap isteri.

Ramadhan (2018) dalam penelitiannya menyebutkan bahwa KDRT sangat berpengaruh terhadap keharmonisan keluarga, dimana kekerasan fisik merupakan kekerasan paling umum yang dilakukan oleh suami terhadap istrinya. Hal ini tentu akan berdampak pada kesejahteraan psikologis istri, seperti yang dikatakan oleh Marchira dkk. (2007) bahwa KDRT memiliki dampak terhadap tingkat kecemasan pada sebagian besar perempuan. 


\section{Kesimpulan}

Dari hasil analisis data dan pembahasan sebelumnya maka dapat disimpulkan bahwa terdapat hubungan negatif yang sangat signifikan antara religiusitas dengan kecenderungan melakukan KDRT oleh suami di Kota Banda Aceh (hipotesis diterima), dengan nilai koefisien korelasi sebesar $\mathrm{r}=-0,788, \mathrm{p}=0,000$. Hal ini menunjukkan semakin tinggi religiusitas yang dimiliki oleh suami maka semakin rendah kecenderungan melakukan KDRT.Begitu juga sebaliknya, semakin rendah religiusitas yang dimiliki oleh suami maka semakin tinggi kecenderungan melakukan KDRT.

Saran

Berdasarkan hasil penelitian ini, maka peneliti dapat menyarankan beberapa hal yaitu penelitian ini dapat memberikan informasi bagi instansi yang menelaah masalah KDRT bahwa adanya hubungan antara religiusitas dengan kecenderungan melakukan KDRT, sehingga instansi tersebut dapat menyusun program untuk mengurangi KDRT dengan berlandaskan pada tuntunan agama. Penelitian ini juga memberikan informasi kepada masyarakat luas tentang pentingnya religiusitas dalam membangun rumah tangga, khususnya pemahaman agama yang benar sehingga dapat dipraktikkan secara baik untuk keharmonisan keluarganya.

\section{Referensi}

Anggarasari, R. E. (1997). Hubungan Tingkat Religiusitas Dengan Sikap Konsumtif Pada Ibu Rumah Tangga. Psikologika: Jurnal Pemikiran dan Penelitian Psikologi, 2(4), 15-20.

At-Tharirah, A. (2006). Kekerasan Rumah Tangga Produk Kapitalisme (Kritik Atas Persoalan KDRT). UIN Sunan Gunung Djati.

Yuhono, E. (2018). Pendampingan Psikologis Bagi Korban Kekerasan Dalam Rumah Tangga (KDRT) di Lembaga Advokasi Perempuan Damar Bandar Lampung [Skripsi (tidak diterbitkan)]. Universitas Negeri Raden Intan.

Hurlock, E. B. (2012). Psikologi perkembangan. Erlangga.

Marchira, C., Amylia, Y., \& Winarso, M. S. (2007). Hubungan Kekerasan dalam Rumah Tangga dengan Tingkat Kecemasan pada Wanita. Berita Kedokteran Masyarakat, 23(3), 119.

Mufidah. (2008). Psikologi Keluarga Islam Berwawasan Gender. UIN Malang Press.

Puspitaningtyas, R. (2004). Profil Perempuan Korban Kekerasan Dalam Rumah Tangga [Skripsi (tidak diterbitkan)]. Universitas Gadjah Mada. 
Ramadhan, R. A. (2018). Pengaruh Kekerasan Dalam Rumah Tangga (KDRT) Terhadap Tingkat Keharmonisan Dalam Keluarga di Kelurahan Umban Sari Kecamatan Rumbai Kota Pekanbaru [Disertasi]. Universitas Riau.

Safaria, T., \& Darokah, M. (2005). Perbedaan Tingkat Religiusitas, Kecerdasan Emosi, dan Keluarga Harmonis Pada Kelompok Pengguna Napza Dengan Kelompok NonPengguna. Humanitas: Jurnal Psikologi Indonesia, 2(2), 89-101.

Situmorang, T. W., \& Syifa, R. (2008). Situmorang, T, W. E Syifa'a, R. (2008).Hubungan antara religiusitas suami dengan intensi melakukan kekerasan dalam rumah tangga. (Skripsi Tidak Dipublikasikan).Fakultas Psikologi dan Ilmu Sosial Budaya.Universitas Islam Indonesia.Yogyakarta. [Skripsi (tidak diterbitkan)]. Fakultas Psikologi dan Ilmu sosial Budaya Universitas Islam Indonesia.

Takariawan. (2004). Agar Cinta Menghiasi Rumah Tangga Kita. Era Intermedia.

\begin{tabular}{|l|l|l|l|l|}
\hline Submit & Review & Revisi & Diterima & Publis \\
\hline 06-04-2020 & 29-04-2020 sd 06-05-2020 & $19-05-2020$ & $04-06-2020$ & $21-06-2020$ \\
\hline
\end{tabular}

Zulfa Rahmah, Syafrilsyah, Fatmawati

Fakultas Psikologi, Universitas Negeri Ar-Raniry, Banda Aceh

Email : rzullfa97@gmail.com, syafrilsyah@ar-raniry.ac.id, fatmawati@ar-raniry.ac.id 